\title{
Evaluation of a Single Probe Capacitance Meter for Esti- mating Herbage Yield
}

\author{
PAT O. CURRIE, THOMAS O. HILKEN, AND RICHARD S. WHITE
}

\begin{abstract}
A single probe electronic capacitance meter for estimating herbage yields was field tested on 2 western wheatgrass (Pascopyrum smithii (Rydb.) Löve), a blue grama (Bouteloua gracilis (H.B.K.) Lag. ex Griffiths), crested wheatgrass (A gropyron cristatum (L.) Grertn.), and Russian wildrye (Psathrostachys juncea (Fisch.) Nevski) stands in the Northern Great Plains. This single probe meter is lightweight, portable, and allows the user to estimate yields of single plants to determine productivity of individual species. Linear regression equations were fitted between probe readings and the green and dry weight of forage clipped from individual plants within a 78.5- $\mathrm{cm}^{2}$ circular plot. An overall coefncient of determination $\left(r^{2}\right)$ of 0.50 was obtained with linear relationships being statistically significant between the probe readings and green and dry weight of forage for all regressions $(P=0.10)$. Considering the regression estimates for $r^{2}$, standard error of the estimate and $F$ values, the best model fit occurred in the western wheatgrass and crested wheatgrass stands. Presence of a litter mat in 1 western wheatgrass stand had little influence on the precision of the instrument, but phenology of the plants strongly influenced meter readings. Therefore, regression lines within a species could not be pooled across all sampling dates. Comparing yields of individual species from the small plots of the single probe meter to yields from a larger, 1,858- $\mathrm{cm}^{2}$ rectangular plot estimated with a multi-probe capacitance meter showed comparisons were not statistically different $50 \%$ of the time. A sample size of approximately 150 plots per species was required for each sample period for the single probe meter.
\end{abstract}

Key Words: litter, phenology, regression analysis, plot size, sample size

Estimates of herbage yields are essential measurements in grassland research. Estimates of above-ground biomass obtained by clipping and weighing the vegetation are labor intensive. However, a more paramount consideration in grassland research is nondestructive sampling of the above-ground herbage. Several nondestructive, labor-saving methods are reviewed by Tucker (1980). Use of a capacitance meter is a technique that has received considerable attention by several workers (Neal and Neal 1965, Alcock and Lovett 1967, Kelly et. al 1969, Carpenter et al. 1973, Currie et al. 1973, Neal et al. 1976, Morris et al. 1976, Terry et al. 1981).

Capacitance meters have provided a rapid, accurate, and nondestructive means of estimating the total yield of above-ground herbage (Morris et al. 1976). However, a major restriction in using the capacitance meter includes its inability to estimate individual species (Pieper 1978). Also, it is recommended that a separate regression estimate be developed for each major phenological stage and vegetation type (Neal and Neal 1973).

A recent innovation for an electronic instrument consists of a single probe electronic capacitance meter (Vickery and Nicol 1982). This meter differs from other previously described electronic meters in that the single probe permits sampling of a small area and individual plants can be sampled if species are discretely

\footnotetext{
Authors are range scientist and plant physiologist, respectively, USDA-ARS, and research associate, MAES, at the Fort Keogh Livestock and Range Research Laboratory, Route 1, Box 2021, Miles City, Montana 59301. Currently, White is with KSU Extension Service, Colby, Kans.

This research is a contribution from the USDA, Agricultural Research Service, Fort Keogh Livestock and Range Research Laboratory and the Montana Agricultural Experiment Station, Journal Series No. J1865.

Manuscript accepted 29 June 1987.
}

distributed. The single probe meter uses a Schmidt-trigger oscillator operating at $6 \mathrm{Khz}$, whereas most herbage meters use Colpitts oscillators operating at $5 \mathrm{Mhz}$. The 5-Mhz oscillators are electronically 800 times more sensitive and therefore, have 800 times greater resolution. ${ }^{1}$ The single probe meter is portable, lightweight $(1.5 \mathrm{~kg})$ and uses integrated circuits to accumulate the sum of the sampleplot readings and the number of plots sampled.

Objectives of our research were to field test the single probe capacitance meter to determine its suitability for estimating the yield from rangeland on homogeneous stands of native and introduced grass stands. The research was conducted at Fort Keogh Livestock and Range Research Stations near Miles City, MT.

\section{Materials}

Use of capacitance meters is based on a premise for a difference in dielectric constant between air which is high and herbage which is low (Neal and Neal 1965, Pieper 1978). Capacitance of the air-herbage mixture is measured by the meter and the herbage clipped and weighed. Regression techniques are used to relate the weight of the herbage to the meter reading. Once regression estimates have been developed, additional yield measurements can be made nondestructively and relatively quickly over a fairly wide range of values.

After extensive laboratory and field tests, Vickery et al. (1980) described a single probe electronic capacitance meter which was reported as being mainly responsive to leaf surface area. They reported this responsiveness was caused by variation in dry matter mass rather than moisture content and concluded that the instrument could be calibrated and used to measure standing dry herbage. It was deemed unnecessary to collect and dry herbage samples for frequent recalibration.

Based upon these results and using design criteria obtained from Vickery and Nicol (1982), Neal Electronics, in 1984, constructed a single probe electronic capacitance meter for the USDA, Agricultural Research Service. This instrument, Model Number 1-62002, followed the general design and construction procedures outlined by Vickery and Nicol (1982) (Fig. 1), but was modified as necessary to accommodate changes and availability of electronic components.

\section{Methods}

Yield estimates of individual plant species were made on 2 native grasses, blue grama (Bouteloua gracilis (H.B.K.) Lag. ex. Griffiths) and western wheatgrass (Pascopyrum smithii (Rydb.) Löve), ${ }^{3}$ occurring in separate homogeneous stands. Individual plants were sampled within 2 stands of western wheatgrass. One stand had been protected from livestock grazing for approximately 5 years and had an appreciable litter mat 3-5 cm thick. The other stand had been grazed annually by livestock so a litter mat had not accumulated. Blue grama was also on an area that had been protected from livestock grazing for 5 or more years. However, litter had not accumulated as it had in the ungrazed western wheatgrass stand.

\footnotetext{
${ }^{1}$ Personal communication with J.L. Neal, Neal Electronics, 544 North Myers Street, Burbank, California 91506.

${ }^{2}$ Mention of a trade name, proprietary product or specific equipment does not constitute a guarantee or warranty by the USDA and does not imply its approval to the exclusion of other products that may be suitable.

3Nomenclature follows that proposed by Dr. D.R. Dewey (1984).
} 


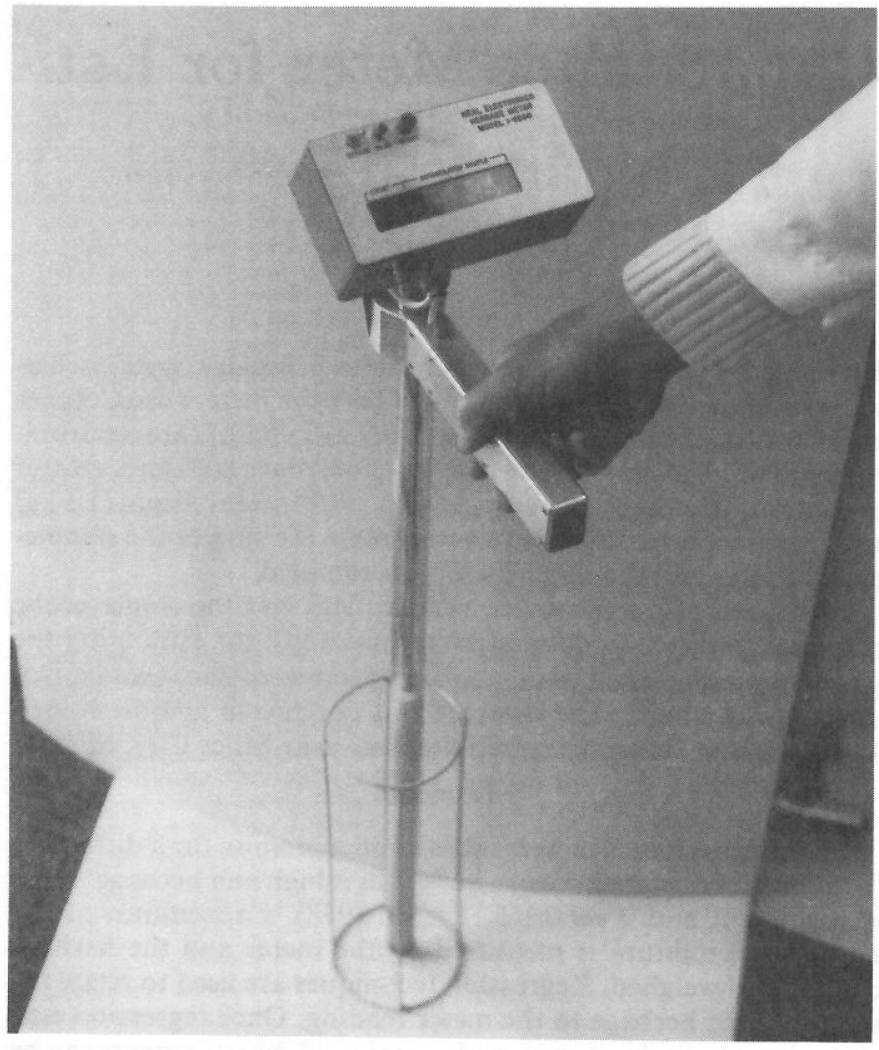

Fig. 1. Components of the single probe capacitance meter illustrating: (I) small box of electronic components containing the counting circuits, an on-off switch and a switch for resetting, (2) liquid crystal display, (3) handle which protrudes below the electronic box and contains batteries, (4) switch to trigger readings, and (5) probe.
Yield of 2 introduced grasses, crested wheatgrass (Agropyron cristatum (L.)Gaertn.) and Russian wildrye (Psathyrostachys juncea (Fisch.) Nevski) were also estimated. Crested wheatgrass was seeded approximately 15 years before and was grazed early each spring. The Russian wildrye was seeded in the fall of 1981 and had been mowed earlier in the summer of 1985. Except for the 1 western wheatgrass stand, both the native and introduced vegetation contained very little standing or matted residual litter.

The single probe meter was tested in each of the 5 grass stands during the field season of 1985 . The western wheatgrass and blue grama stands were sampled at different calendar dates during the field season, while the crested wheatgrass and Russian wildrye stands were sampled only once. Date, sample size and phenological stage of grasses when yield determinations were made are given in Table 1.

Meter readings for the pasture probe were made for each grass stand at 3-m intervals along a pace transect. Specific points were sampled by randomly placing the probe on the ground or within individual plants of that vegetation type and obtaining a meter reading. After the ground or vegetation point reading had been obtained, an atmospheric reading was taken at that same point by holding the meter probe approximately 1 meter above the ground surface. Subsequently, a 10-cm diameter cylindrical metal plot with an area of $78.5 \mathrm{~cm}^{2}$ and frame with 4 rods extending to a $31-\mathrm{cm}$ height was centered around the plant being estimated (Fig. 2). Herbage within this cylindrical plot was clipped to ground level following the 3-dimensional clipping procedure outlined by Currie et al. (1973). Then a larger $30.5 \times 60.9-\mathrm{cm}$ rectangular plot with an area of $1,858 \mathrm{~cm}^{2}$ was sampled. Green and dry weights were recorded for both sized plots. To assure homogeneity in sampling, the rectangular plot was placed over the area where the smaller cylindrical plot had been clipped and the remaining vegetation was clipped to ground level. The small cylindrical plot samples were dried in a 700 watt microwave oven at high power for approximately $4 \mathrm{~min}$. The large rectangular plot samples were dried at $100^{\circ}$ $\mathrm{C}$ for 12 hours in a convection oven. The small $10-\mathrm{cm}$ diameter plot $\left(78.5 \mathrm{~cm}^{2}\right)$ was compared to the large plot $\left(1,858 \mathrm{~cm}^{2}\right)$ because the

Table 1. Details of individual regressions fitted to single probe capacitance meter data obtained from 5 study sites across different sampling dates on a green and dry weight basis. ${ }^{1}$

\begin{tabular}{|c|c|c|c|c|c|c|c|c|c|c|c|c|c|}
\hline \multirow{2}{*}{$\begin{array}{l}\text { Grass } \\
\text { Stand }\end{array}$} & \multirow{2}{*}{$\begin{array}{c}\text { Date } \\
(1985)\end{array}$} & \multirow{2}{*}{$\begin{array}{l}\text { Sample } \\
\text { Size }\end{array}$} & \multirow{2}{*}{ Phenological Stage } & \multirow{2}{*}{$\begin{array}{l}\text { Weight } \\
\text { Basis }\end{array}$} & \multicolumn{3}{|c|}{ Intercept } & \multicolumn{4}{|c|}{ Regression Coefficient } & \multirow[b]{2}{*}{$r^{2}$} & \multirow[b]{2}{*}{ sy. $\chi$} \\
\hline & & & & & a & \pm & S.E. & $\mathrm{b}$ & \pm & S.E. & F-Value & & \\
\hline $\operatorname{PASM}(\mathrm{L})^{2}$ & $5 / 14$ & 20 & $\begin{array}{l}\text { Pre-boot, vegetative } \\
\text { Boot, mature }\end{array}$ & $\begin{array}{l}\text { Green } \\
\text { Dry } \\
\text { Green } \\
\text { Dry }\end{array}$ & $\begin{array}{l}-0.1140 \\
-0.1470 \\
-1.2520 \\
-0.8420\end{array}$ & $\begin{array}{l} \pm \\
\pm \\
\pm \\
\pm\end{array}$ & $\begin{array}{l}0.1255 \\
0.0527 \\
0.2009 \\
0.1278\end{array}$ & $\begin{array}{l}0.0066 \\
0.0029 \\
0.0128 \\
0.0068\end{array}$ & $\begin{array}{l} \pm \\
\pm \\
\pm \\
\pm\end{array}$ & $\begin{array}{l}0.0016 \\
0.0007 \\
0.0022 \\
0.0014\end{array}$ & $\begin{array}{l}17.76 \\
19.97 \\
33.88 \\
23.85\end{array}$ & $\begin{array}{l}0.49 \\
0.53 \\
0.64 \\
0.56\end{array}$ & $\begin{array}{l}0.56 \\
0.24 \\
0.96 \\
0.61\end{array}$ \\
\hline $\operatorname{PASM}(\mathrm{N})^{3}$ & $\begin{array}{l}5 / 15 \\
6 / 30 \\
9 / 13\end{array}$ & 20 & $\begin{array}{l}\text { Pre-boot, vegetative } \\
\text { Boot, mature } \\
\text { Fall growth, vegetative }\end{array}$ & $\begin{array}{l}\text { Green } \\
\text { Dry } \\
\text { Green } \\
\text { Dry } \\
\text { Green } \\
\text { Dry }\end{array}$ & $\begin{array}{l}-0.2476 \\
-0.2488 \\
-2.2311 \\
-1.2386 \\
-0.6396 \\
-0.3038\end{array}$ & $\begin{array}{l} \pm \\
\pm \\
\pm \\
\pm \\
\pm \\
\pm\end{array}$ & $\begin{array}{l}0.1135 \\
0.0491 \\
0.3421 \\
0.1647 \\
0.0938 \\
0.0279\end{array}$ & $\begin{array}{l}0.0094 \\
0.0042 \\
0.0161 \\
0.0086 \\
0.0090 \\
0.0036\end{array}$ & $\begin{array}{l} \pm \\
\pm \\
\pm \\
\pm \\
\pm \\
\pm\end{array}$ & $\begin{array}{l}0.0020 \\
0.0009 \\
0.0042 \\
0.0020 \\
0.0018 \\
0.0005\end{array}$ & $\begin{array}{l}21.94 \\
24.15 \\
14.48 \\
17.66 \\
24.23 \\
43.76\end{array}$ & $\begin{array}{l}0.55 \\
0.58 \\
0.45 \\
0.49 \\
0.46 \\
0.61\end{array}$ & $\begin{array}{l}0.51 \\
0.23 \\
1.65 \\
0.81 \\
0.54 \\
0.18\end{array}$ \\
\hline $\mathrm{AGCR}^{4}$ & $8 / 30$ & 30 & Fall growth, vegetative & $\begin{array}{l}\text { Green } \\
\text { Dry }\end{array}$ & $\begin{array}{l}-1.0781 \\
-0.3354\end{array}$ & $\begin{array}{l} \pm \\
\pm\end{array}$ & $\begin{array}{l}0.1628 \\
0.0588\end{array}$ & $\begin{array}{l}0.0118 \\
0.0043\end{array}$ & $\begin{array}{l} \pm \\
\pm\end{array}$ & $\begin{array}{l}0.0019 \\
0.0007\end{array}$ & $\begin{array}{l}36.66 \\
36.65\end{array}$ & $\begin{array}{l}0.56 \\
0.56\end{array}$ & $\begin{array}{l}0.96 \\
0.34\end{array}$ \\
\hline BOGR $^{5}$ & $\begin{array}{l}5 / 09 \\
6 / 30 \\
9 / 18\end{array}$ & $\begin{array}{l}20 \\
20 \\
30\end{array}$ & $\begin{array}{l}\text { Pre-boot, vegetative } \\
\text { Boot, mature } \\
\text { Fall growth, vegetative }\end{array}$ & $\begin{array}{l}\text { Green } \\
\text { Dry } \\
\text { Green } \\
\text { Dry } \\
\text { Green } \\
\text { Dry }\end{array}$ & $\begin{array}{r}-0.1605 \\
-0.1289 \\
0.6550 \\
0.1140 \\
0.0529 \\
0.0165\end{array}$ & $\begin{array}{l} \pm \\
\pm \\
\pm \\
\pm \\
\pm \\
\pm\end{array}$ & $\begin{array}{l}0.0439 \\
0.0269 \\
0.0548 \\
0.0444 \\
0.0340 \\
0.0242\end{array}$ & $\begin{array}{l}0.0046 \\
0.0029 \\
0.0028 \\
0.0024 \\
0.0027 \\
0.0023\end{array}$ & $\begin{array}{l} \pm \\
\pm \\
\pm \\
\pm \\
\pm \\
\pm\end{array}$ & $\begin{array}{l}0.0009 \\
0.0006 \\
0.0007 \\
0.0006 \\
0.0009 \\
0.0006\end{array}$ & $\begin{array}{r}24.04 \\
24.36 \\
14.73 \\
15.49 \\
9.29 \\
13.58\end{array}$ & $\begin{array}{l}0.58 \\
0.56 \\
0.45 \\
0.46 \\
0.25 \\
0.34\end{array}$ & $\begin{array}{l}0.20 \\
0.12 \\
0.34 \\
0.20 \\
0.19 \\
0.13\end{array}$ \\
\hline PSJM 6 & $8 / 28$ & 30 & Fall growth, vegetative & $\begin{array}{l}\text { Green } \\
\text { Dry }\end{array}$ & $\begin{array}{l}-2.0324 \\
-1.6545 \\
\end{array}$ & $\begin{array}{l} \pm \\
\pm\end{array}$ & $\begin{array}{l}0.3004 \\
0.1679 \\
\end{array}$ & $\begin{array}{l}0.0197 \\
0.0118 \\
\end{array}$ & $\begin{array}{l} \pm \\
\pm\end{array}$ & $\begin{array}{l}0.0054 \\
0.0030 \\
\end{array}$ & $\begin{array}{l}13.53 \\
15.33 \\
\end{array}$ & $\begin{array}{l}0.32 \\
0.35\end{array}$ & $\begin{array}{l}1.68 \\
0.96\end{array}$ \\
\hline
\end{tabular}

${ }^{1}$ Regression of herbage mass $\left(\mathrm{g} / 78.5 \mathrm{~cm}^{2}\right)$ on capacitance meter reading.

${ }^{2}$ Western wheatgrass with litter.

${ }^{3}$ Western wheatgrass no litter.

${ }^{4}$ Crested wheatgrass.

${ }^{5}$ Blue grama.

${ }^{6}$ Russian wildrye. 
Table 2. Comparison of green and dry weight yields between the large and small plot sizes and actual and estimated sample sizes.'

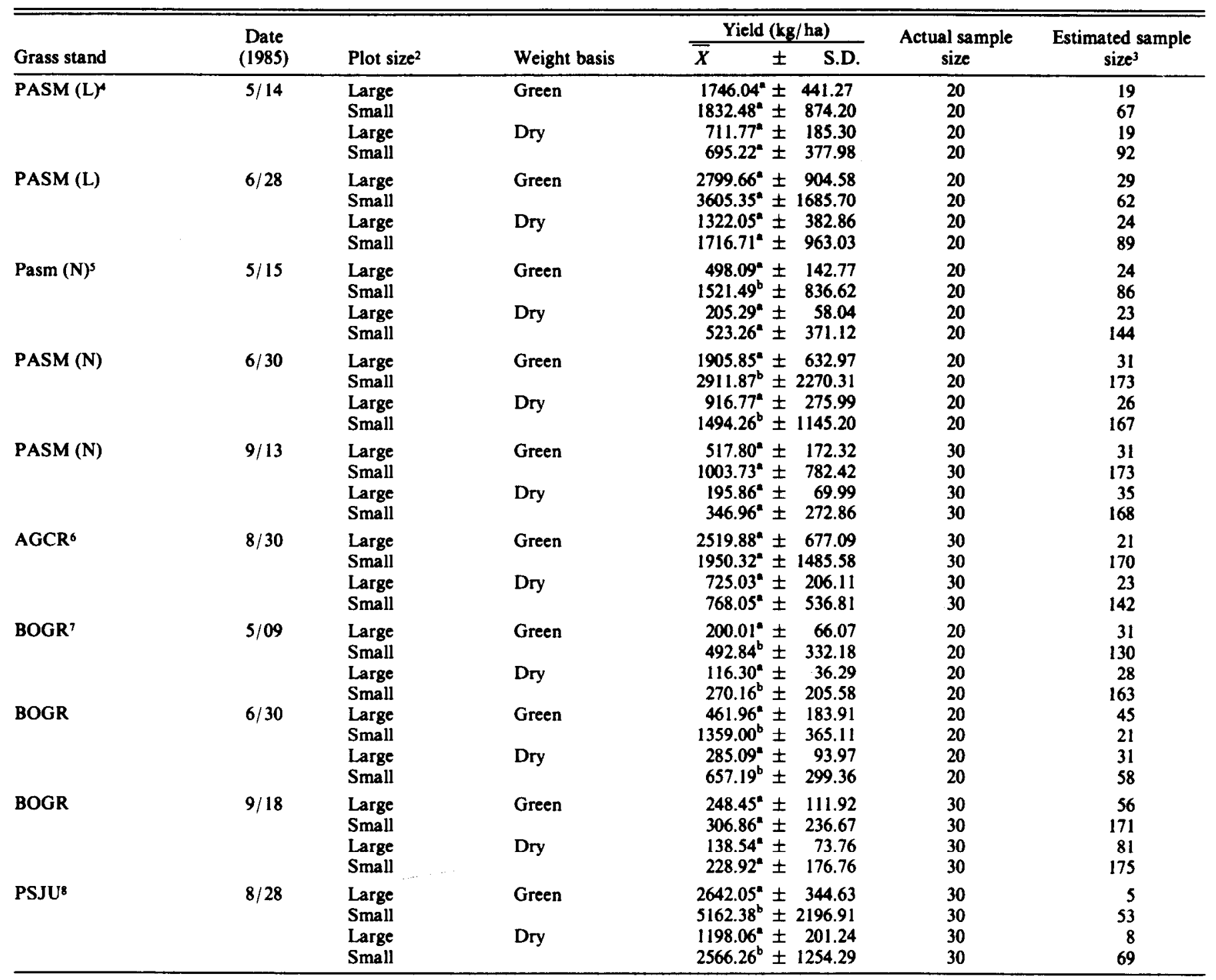

'Statistical comparisons of yields were made between plot sizes (large vs. small) within species, dates and weight basis. Pairs followed by different letters were significantly different $(P \leq 0.10)$.

${ }^{2}$ Large plot size was $1.858 \mathrm{~cm}^{2}$ and small plot size $78.5 \mathrm{~cm}^{2}$.

${ }^{3}$ Estimated sample size to achieve $10 \%$ of $\bar{X}$ at $P<0.05$.

Western wheatgrass with litter.

sWestern wheatgrass no litter.

${ }^{\circ}$ Crested wheatgrass.

'Blue grama.

${ }^{8}$ Russian wildrye

larger plot is typically used with multi-probe capacitance meters.

A corrected single probe reading was calculated by subtracting the vegetation point reading from the atmospheric reading. A corrected reading was used as recommended by Vickery and Nicol (1982). The premise is that this makes a substantial improvement in the calibration regression and also provides a method of accounting for any drift or change in the electronic response of the instrument due to changes in temperature of the oscillator components as a result of changes in ambient temperature. Regression equations were then fitted using the corrected pasture probe readings as an independent variable and the green and dry weights of the forage within the $10-\mathrm{cm}$ diameter plots as a dependent variable. Blue grama and western wheatgrass stands were sampled more than once during the season, and regression equations were compared across sampling dates within each of the grass stands. Regression for the western wheatgrass stands with and without a litter mat were compared to determine the influence of the litter mat. Also, these stands had been selected for homogeneity of species so that presumably only one species was sampled per stand.

\section{Statistical Analyses}

Comparisons of regression estimates were made following procedures outlined by Neter and Waserman (1974). This procedure compares the general equality of the slopes and intercepts between 2 or more simple regression functions $\left(\mathbf{Y}_{i}=\mathbf{B}_{0}+\mathbf{B}_{\mathbf{0}}+\mathbf{B}_{1} \mathbf{X}_{\mathrm{i}}\right)$. If 2 lines of the full models were equal, they were pooled into 1 and a reduced model was fit from the combined data. Overall equality of regression lines were tested for the following hypotheses:

Ho: $B_{01}=B_{02}$ and $B_{11}=B_{12}$ where, 1 and 2 were a separate set of equations. The regression estimates were evaluated on significance of the 


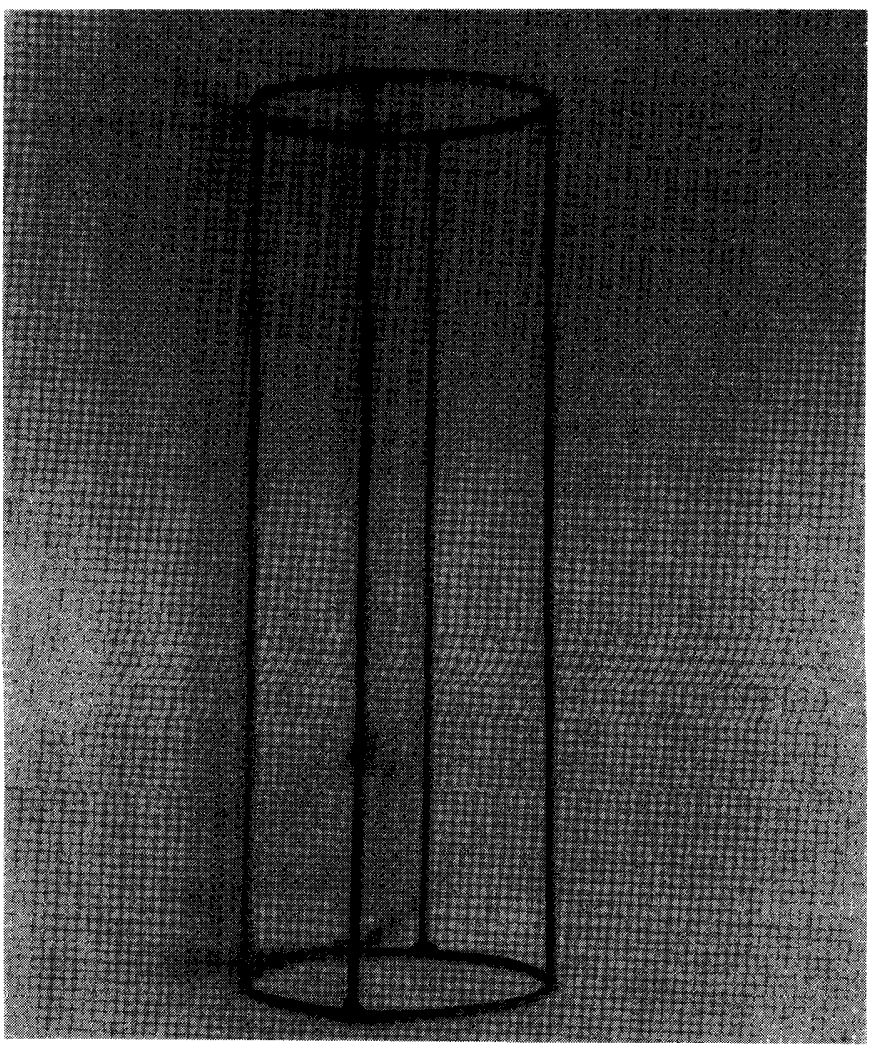

Fig. 2. Cylindrical volume plot used in making yield estimate by the single probe meter.

following criteria: $F$ value of the regression coefficient, coefficient of determination $\left(r^{2}\right)$, and standard error of the estimate (sy. $\left.\chi\right)$. The inadequacy of using $r^{2}$ as the only basis for evaluating the relation of herbage yield to meter estimates has been pointed out by Neal et al. (1976) and Back (1968). A 90\% confidence interval was calculated for all correlation coefficient $(r)$ values to determine if the linear relationship between the $\mathrm{x}$ and $\mathrm{y}$ variables was statistically significant. The relationship was not considered significant if zero was included in the confidence interval (Neter and Waserman 1974).

Yield estimates between the small circular plot and the large rectangular plot were compared by first determining the weight in small plots to obtain that estimate and then adding the weight of the small plot to the large plot for the large plot estimate. This was done for green weights and dry weights, respectively. A one-way analysis of variance procedure (Steel and Torrie 1960) was used to make individual comparisons of yield estimates. Steins 2-stage sample procedure (Steel and Torrie 1960) was used to estimate sample size for the small and large plots. Sample size was calculated to obtain a weight estimate within $10 \%$ of the sample mean at the 0.05 probability level.

\section{Results and Discussion}

The $90 \%$ confidence interval calculated for each individual $r$ did not include zero and therefore, a significant linear trend between meter reading (x) and green and dry weight (y) existed for all regressions (Table 1). An $r^{2}$ was calculated for all green and forage estimates for all regressions. Approximately $50 \%$ of the variation was accounted for by the regression equations with an average sy. $\chi$ of 0.57 . Based upon the regression criteria (sy. $\chi, r^{2}$ and $F$ values), the regression models for the western wheatgrass and crested wheatgrass locations in our study showed stronger linear relationships than the models for the late sampling date on the blue grama and Russian wildrye stands. The model with the poorest fit was on the Russian wildrye stand. For this species, the weak relationship between the $x$ and $y$ variables may be attributable to the inability of people clipping to accurately harvest decumbent or low growing grasses. The sy. $\chi$ were typically higher on a green weight basis than on a dry weight basis for all regressions, and this difference probably accounts for different sample size requirements between the 2 weight estimates.

In a grazed pasture of Phalaris aquatica-Trifolium repens, Vickery et al. (1980) reported that a single probe pasture meter accounted for more than $86 \%$ of the variance between herbage yields and corrected meter readings. Also, relationships between the $x$ and $y$ variables might be improved by increasing sample size, employing a logarithmic or reciprocal transformation of the regression function or using a polynomial regression (Neter and Wasserman 1974). Terry et al. (1981), using an 18-probe meter on a south Florida flatwood rangeland, found that regression comparisons based on scatter depths, $r^{2}$, and Furnival's indices gave improved predictability if both dry weights and meter readings were expressed on logarithmic rather than linear scales.

In the western wheatgrass stand, the presence of a litter mat did not significantly change the $r^{2}$, sy. $\chi$, or $F$ values of the regression function compared to the other fitted regressions for the other species (Table 1). The best model fit was on the western wheatgrass stand with litter during the early sample date. In other studies, Neal et al. (1976) using an 18-probe capacitance meter and working with different species under different environmental conditions reported that yield estimates were much more precise when litter was removed. However, Currie et al. (1973) reported that separation of dead organic matter from living plant material did not significantly change the $r^{2}$ values, although this dead organic matter could contribute significantly to variation of the estimate about the regression line. The present data supported this conclusion and suggested that the presence of a litter mat had very little influence on the accuracy of the meter in predicting green and dry weight yields.

Out of 22 comparisons made, only 8 could be pooled into a combined full model and only 3 of those were on a dry weight basis. By comparing the regression models for the western wheatgrass stand with and without litter during the late sampling period, it was evident that the data for the 2 reduced models could be pooled into 1 full model. However, comparing the regression models between the 2 western wheatgrass stands during the early sampling period showed that the reduced linear regression models were significantly different from one another and a pooled full model could not be calculated. Despite 8 comparisons which showed equality, there were statistical differences between other comparisons for dates within a species. For example, a pooled full model could not be calculated for dry matter yield in relation to pasture probe meter reading for western wheatgrass with litter during the early and late sampling period (Fig. 3). Such differences suggest variations in plant phenology may be a contributing factor because these differences can be attributed to differences in dry matter percentages (Lovett and Burch 1972). Further testing is desirable to evaluate this factor more precisely and determine exactly how plant litter and phenology influence the single probe meter.

Comparison of yields between the small single probe meter plot $\left(78.5 \mathrm{~cm}^{2}\right)$ and the conventional large plot $\left(158 \mathrm{~cm}^{2}\right)$ meter showed that yields from the 2 different plot sizes were statistically similar in about $50 \%$ of the comparisons (Table 2). In all cases, estimated yields for green and dry weight from the small circular plot were larger than those from the large rectangular plot on a per hectare basis. Pieper (1978) presented a possible explanation. He states the psychology of people clipping vegetation is to include more material along the edge of a small plot than a large plot, but few studies have been designed to consider this problem. Pieper (1978) further reported that as plot size decreases, the perimeter to area ratio increases and this becomes a factor in precision of the estimate. Van Dyne et al. (1963) found that herbage weight of bunchgrass 


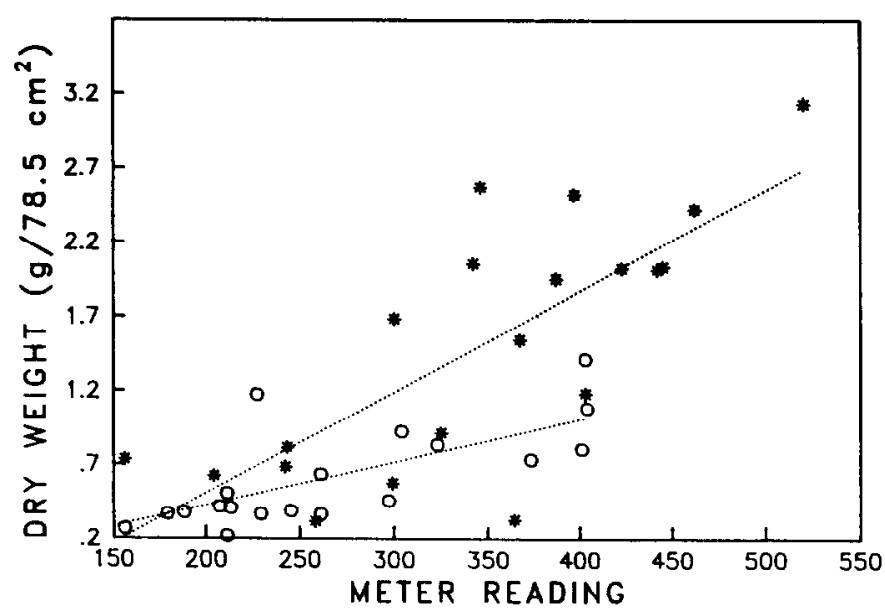

Fig. 3. Scatter diagram of dry matter yield $(y)$ in relation to single probe capacitance meter reading $(x)$ for 2 reduced models of western wheatgrass with litter during early and late sampling date. " = late sampling date, $0=$ early sampling date.

vegetation increased from 6.2 to $6.8 \mathrm{grams}$ per square foot as the perimeter to area ratio increased from 2.3 to 3.0 . in addition to the perimeter to area ratio, plot placement may be another contributing factor. In the Russian wildrye stand, the rectangular plot was placed directly over the center of each individual row; thus, a biased estimate of yield can occur. This problem was recognized and a sampling procedure using the $1,858 \mathrm{~cm}^{2}$ rectangular plot was described for seeded ranges by Currie et al. (1973). In the future, a sampling procedure employing the single probe meter needs to be evaluated for obtaining an unbiased surface area estimate of species that occur in rows.

Stein's 2-stage sample procedure (Steel and Torrie 1960) was used on both large and small plots to calculate the clipped plot sample size needed to estimate the population mean within the limits given. An overall average sample size calculated for the small circular plot was $110 \pm 56$ and $125 \pm 42$ on a green and dry weight basis, respectively. The estimated plot number for the large rectangular plot on a green and dry weight basis was $29 \pm 13$ and $29 \pm 18$, respectively.

\section{Recommendations}

The single probe capacitance meter is useful for estimating individual species yield on both a dry and green weight basis in homogeneous stands. Using the meter in conjunction with cover estimates could provide yield estimates for individual species that occur in heterogeneous stands. Results showed a difference in meter estimates between stages of plant phenology, therefore, we recommend using a double sampling procedure or developing a new calibration curve for each sampling date and location. This is contrary to the recommendations of Vickery et al. (1980) who suggested development and use of a standardized curve. Thus far, we have not been able to develop a single curve that is suitable for an all inclusive yield estimate, and in our work, it appears that the meter is responding to variables other than surface areas as postulated by Vickery et al. (1980).

Further studies are desirable to determine how often calibration is needed and the optimum ratio of clipped samples to meter estimated plots when using a double sampling procedure. We believe that the accuracy of the estimate will probably improve when a sample size of approximately 150 is used in any one grass stand. Sampling procedures also need to be evaluated for obtaining an unbiased estimate of species that occur in rows when using the single probe meter. Further clarification is also needed regarding the spatial area of the plot of vegetation being sensed. Questions exists as to whether or not it is cylindrical, remains constant in size and is independent of amount of vegetation in the cylinder. These factors may be critical since the area being sensed by the probe may be independent of the shape of the plot which is most efficient in relation to clipping procedures.

\section{Literature Cited}

Alcock, M.B., and J.V. Lovett. 1967. The electronic measurement of the yield of growing pasture: I. A Statistical assessment. J. Agr. Sci. 27-38.

Back, H.L. 1968. An evaluation of an electronic instrument for pasture yield estimation. Part 1. General relationships. J. Brit. Grassl. Soc. 23:216-222.

Carpenter, L.H., O.C. Wallmo, and M.J. Morris. 1973. Effect of woody stems on estimating herbage weights with a capacitance meter. J. Range Manage. 26:151-153.

Currie, P.O., M.J. Morris, and D.L. Neal. 1973. Uses and capabilities of electronic instruments for estimating standing herbage. Part 2. Sown ranges. J. Brit. Grassl. Soc. 28:155-160.

Dewey, D.R. 1984. The genomic system of classification as a guide to intergeneric hybridization with the perennial Triticeae. In: J.P. Gustafson (ed.) Gene Manipulation in Plant Improvement. 209-279.

Kelly, J.M., P.A. Opstrup, J.S. Olson, S.I. Averbach, and G.M. Van Dyne. 1969. Models of seasonal primary productivity in eastern Tennessee Festuca and Andropogon ecosystems. Oak Ridge National Lab. ORNL4310 O.C. 48-Biology and Medicine.

Lovett, J.V., and C.J. Burch. 1972. The electronic measurement of small herbage yields using a high sensitivity capacitance meter. J. Brit. Grassl. Soc. 27:83-86.

Morris, M.J., K.L. Johnson, and D.L. Neal. 1976. Sampling shrub ranges with an electronic capacitance instrument. J. Range Manage. 29:78-81.

Neal, D.L., and J.L. Neal. 1965. A new electronic meter for measuring herbage yield. U.S. Forest Serv. Res. Note PSW-56.

Neal, D.L., and J.L. Neal. 1973. Uses and capabilities of electronic capacitance instruments for estimating standing herbage. Part 1 . History and Development. J. Brit. Grassl. Soc. 23:81-89.

Neal, D.L., P.O. Currie, and M.J. Morris. 1976. Sampling herbaceous native vegetation with an electronic capacitance instrument. J. Range Manage. 29:74-77.

Neter, J., and W. Wasserman. 1974. Applied linear statistical methods. Richard D. Irwin, Inc. Homewood, Ill.

Pieper, R.D. 1978. Measurement techniques for herbaceous and shrubby vegetation. Dep. of Animal and Range Sciences, New Mexico State Univ., Las Cruces, New Mexico.

Steel, R.G.D., and J.H. Torrie. 1960. Principles and procedures of statistics. McGraw-Hill Book Co., Inc. New York.

Terry, S.W., D.H. Hunter and B.F. Swindel. 1981. Herbage capacitance meter: an evaluation of its accuracy in Florida rangelands. J. Range Manage. 3:240-242.

Tucker, C.J. 1980. A critical review of remote sensing and other methods for nondestructive estimation of standing crop biomass. Grass and Forage Sci. 35:177-182.

Van Dyne, G.M., W.G. Vogel, and H.G. Fisser. 1963. Influence of small plot size and shape on range herbage production estimates. Ecology 44:746-759.

Vickery, P.J., and G.R. Nicol. 1982. An improved electronic capacitance meter for estimating pasture yield. Construction details and performance tests. Anim. Res. Lab. Tech. Paper No. 9. Commonwealth Scientific and Industrial Research Organization, Australia.

Vickery, P.J., I.L. Bennett, and G.R. Nicol. 1980. An improved electronic capacitance meter for estimating herbage mass. Grass and Forage Sci. 35:247-252 